\title{
Engineering of Carbonate Apatite Bone Substitute Based on Composition-Transformation of Gypsum and Calcium Hydroxide
}

\author{
Ika Dewi Ana ${ }^{1}$, Shigeki Matsuya ${ }^{2}$, Kunio Ishikawa ${ }^{3}$ \\ ${ }^{1}$ Department of Dental Biomedical Sciences, Faculty of Dentistry, \\ Gadjah Mada University, Yogyakarta, Indonesia \\ ${ }^{2}$ Section of Bioengineering, Department of Dental Engineering, Fukuoka Dental College, Fukuoka, Japan \\ ${ }^{3}$ Department of Biomaterials, Faculty of Dental Science, Kyushu University, Fukuoka, Japan \\ E-mail: ikadewiana@ugm.ac.id \\ Received November 29, 2009; revised February 7, 2010; accepted February 12, 2010
}

\begin{abstract}
Even though a lot of research has been carried out concerning the preparation of carbonate apatite (CHA), they were related to CHA in the form of powder. In the present study, macroporous CHA bone substitutes were prepared through composition-transformation of gypsum and Ca-hydroxide. Here, we investigated the effect of added Ca-hydroxide to gypsum, carbonation periods, and hydrothermal temperatures for phosphatization to understand the basic principle of composition-transformation of gypsum added Ca-hydroxide to fabricate CHA bone substitutes. The specimens were characterized in terms of chemical and physical properties, such as extent of transformation of macroporous gypsum added Ca-hydroxide into CHA body, type and content of carbonate, and crystal morphology. It was observed that the transformation was faster with higher hydrothermal temperature. However, higher hydrothermal temperature caused de-carbonation phenomena which resulted in the lack of carbonate ions of the product. Moreover, the higher the percentage of Ca-hydroxide added to gypsum, caused the complete transformation of gypsum into CHA to be slower. These findings have been applied to the standard fabrication procedure of carbonate apatite, which in turn will allow scaling up process, and will be provided for biomedical purposes for the Indonesian community.
\end{abstract}

Keywords: Carbonate Apatite (CHA), Bone Substitute, Composition-Transformation, Gypsum, Calcium Hydroxide

\section{Introduction}

Bone tissue is one of the most frequently used tissues for transplantation. Annually more than a million patients are treated worldwide for skeletal problems in the field of orthopedic surgery, plastic surgery, maxillofacial surgery, and neurosurgery. The use of autologous bone grafts is still considered to be the golden standard, but there are several major disadvantages in this technique, for example: 1) low availability of transplantable tissue, 2) postoperative morbidity, and 3) lack of functional shape of the transplant. Meanwhile, despite four decades of the researches to provide synthetic bone substituting materials, the engineered bone-substituting materials are still largely inferior to auto- or allografts as the golden standard. The clinical success of the current generation of bone-substituting materials is disappointingly limited since they lack the high functionality of bone tissue in terms of biological and mechanical properties [1]. This lack of biofunctionality is related mainly to an engineering attitude towards design of novel biomaterials that lacks a biological mindset [2,3]. Therefore, the development of alternatives to autologous bone is a very relevant engineering issue in bone reconstructive surgery.

To provide the answer to the issue, the basic knowledge on the composition of human bone mineral must be understood. In view of this, it is known from the current studies that the mineral phase of human hard tissue consists of hydroxyapatite (HA: $\left.\mathrm{Ca}_{10}\left(\mathrm{PO}_{4}\right)_{6}(\mathrm{OH})_{2}\right)$ containing a variety of impurity ions such as carbonate, sodium, and magnesium, etc. [4-8]. Carbonate is one of the most abundant impurity ions and its content is about wt $4-8 \%$ [9-11]. In this sense, hard tissue is regarded as carbonate-substituted HA (CHA). 
It has been reported that synthetic CHA revealed the biological activity better than synthetic HA because the incorporation of carbonate into HA caused an increase in solubility, a decrease in crystallinity, a change in crystal morphology, and an enhancement of chemical reactivity owing to the weak bonding $[5,12,13]$. In this context, CHA is actually more soluble in vivo than HA and increases the local concentration of calcium and phosphate ions that are necessary for new bone formation [14-16]. For these reasons, recent studies have focused on CHA in comparison with HA.

Even though a lot of research has been carried out concerning the preparation of CHA, they were related to CHA in the form of powder $[10,12,17-19]$. In the present study, macroporous CHA bone substitutes were prepared through composition-transformation of gypsum and $\mathrm{Ca}-$ hydroxide, the abundant minerals in Indonesia. The successful composition-transformation process will allow the modification of the macroporous CHA body to provide bone-substitutes with proper mechanical and biological properties, based on the needs of reconstructive surgeon. The specimens were characterized in terms of chemical and physical properties, such as extent of transformation of $\mathrm{CaCO}_{3}$ body into CHA body, type and content of carbonate, and crystal morphology.

This research was also basically directed to find a low cost technology and environmental friendly method to prepare CHA bone substitutes. Its aim is to provide lower cost bone substitutes for the Indonesian market to help the people improve their quality of life. Many related cases showed low access to bone-substitution treatment due to the high cost of medical treatment in which it needs engineering approach to solve the problems.

\section{Materials and Method}

\subsection{Composite Preparation}

Calcium sulphate hemihydrate $\left(\mathrm{CaSO}_{4} \cdot 1 / 2 \mathrm{H}_{2} \mathrm{O}\right)$ of Wako Pure Chemical (Japan) was added by 20, 40, 50, and 100 weight $\%$ of Calcium hydroxide $\left(\mathrm{Ca}(\mathrm{OH})_{2}\right)$ of Nacalai Tesque, Kyoto (Japan). The weight $\%$ of added Ca- hydroxide applied in this study was based on the preliminary studies done ranging from 0 to $100 \%$ Ca-hydroxide additions. The gypsum added Ca-hydroxide powders were used to prepare a monolith by mixing the powder with water in 1:2 W/P. The mixture was put in a stainless steel mold ( $6 \mathrm{~mm}$ in inner diameter by $3 \mathrm{~mm}$ thickness) and pressed uniaxially at $10 \mathrm{MPa}$ to prepare $\mathrm{CaSO}_{4} /$ $\mathrm{Ca}(\mathrm{OH})_{2}$ composite. The composite was then put into $37^{\circ} \mathrm{C}$ incubator with $80 \%$ humidity for 24 hour to allow it to set completely.

\subsection{Composite Carbonation}

The composite was placed in carbon dioxide reaction vessel for 72 hours at room temperature. The reaction vessel (approximately 5L) was saturated with water vapor and carbon dioxide gas was supplied at a rate of 0.15 to $0.20 \mathrm{~L} / \mathrm{min}$.

\subsection{Hydrothermal Treatment}

The composite monolith was then treated hydrothermally in $1 \mathrm{M}$ phosphate solutions at $60^{\circ} \mathrm{C}$ for various times, ranging from 3 to 14 days. The phosphate used was tri-sodium phosphate $\left(\mathrm{Na}_{3} \mathrm{PO}_{4} \cdot 12 \mathrm{H}_{2} \mathrm{O}\right.$; Wako Chemicals, Japan). Each monolith after the hydrothermal treatment was washed with distilled water for $6 \mathrm{~h}$ to eliminate soluble ions.

\subsection{X-Ray Diffraction Analysis}

The purity and crystallite size of the CHA formed were determined by XRD (RINT 2500V, Rigaku, Japan) analysis. The XRD pattern was obtained in the range of $2 \mathrm{~h}$ from $2 \theta^{\circ}$ of 10 to 60 in a continuous mode at a scanning rate of $2 \% \mathrm{~min}$.

\subsection{Fourier Transformed Infrared (FT-IR) Analysis}

Infrared spectra between 400 and $4,000 \mathrm{~cm}^{-1}$ were recorded on the FT-IR spectrometer (Spectrum 2000, Perkin-Elmer, USA) to examine structural changes by the hydrothermal treatment, in particular, $\mathrm{CO}_{3}{ }^{2-}$ ions substituting for $\mathrm{PO}_{4}^{3-}$ and/or $\mathrm{OH}^{-}$ions.

\subsection{Scanning Electron Microscope (SEM) Analysis}

The morphology of fracture surface and crystal shape were observed by SEM (JSM 5400LV, JEOL, Japan) at an acceleration voltage of $15 \mathrm{kV}$ after gold sputtering.

\subsection{Chemical Analysis}

Chemical analysis was also done to determine carbon and nitrogen contents using CHN elemental analyzer (CHN coder MT-6, Yanaco, Japan). Calcium and phosphorus content were determined by Ion-meter (TOADKK Model IM-55G, TOA, Japan) and a spectrometer (UV-Spectrometer, JASCO, Japan) respectively.

\subsection{Mechanical Analysis}

Diametral tensile strength of the composite monolith was evaluated at a constant crosshead speed of $1 \mathrm{~mm} / \mathrm{min}$ on a 
universal testing machine (SV-301, IMADA, Japan). For each experimental condition ten specimens were tested.

\section{Results and Discussion}

\subsection{X-Ray Diffraction Patterns}

Figure 1 shows XRD patterns of gypsum added Ca- hydroxide composite after 72 hours carbonation. It was detected that $\mathrm{CaCO}_{3}$ (calcite) peaks were developed by carbonation regardless the percentage of $\mathrm{Ca}$-hydroxide addition, shown by the peak development at around $2 \theta$ of $28.5^{\circ}$. However, the complete transformation into $\mathrm{CaCO}_{3}$ was faster in the monolith containing $100 \%$ Ca-hydroxide. Other compositions (20, 40, and 50\% addition) transformed into biphasic $\mathrm{DCPD} / \mathrm{CaCO}_{3}$ which was shown by peaks (121) at around $2 \theta$ of $21^{\circ},(141),(112)$ and (121) at around $2 \theta$ of 29 to $31^{\circ}$, and at around $2 \theta$ of $34^{\circ}$ for (022) and (150).

It was also shown in the Figure 1 that the $\mathrm{CaCO}_{3}$ resulted in the carbonation reaction has broader peaks than the commercially available one, indicating that the crystallite size of $\mathrm{CaCO}_{3}$ resulted by carbonation was much smaller. Ca-hydroxide was completely transformed into $\mathrm{CaCO}_{3}$ after 72 hours carbonation, in a single phase or in the form of biphasic $\mathrm{DCPD} / \mathrm{CaCO}_{3}$. Up to this reaction stage, it is expected that the carbonation products will show good tissue response to be applied for biomedical purposes. This is due to the composition transformation into low crystalline $\mathrm{CaCO}_{3}$ that has similar biological properties with aragonite, which is the constituent of marine coral [20]. In case of biphasic $\mathrm{DCPD} / \mathrm{CaCO}_{3}$, it was also reported that DCPD is considered to be HA precursor [21]

Figure 2 shows XRD patterns of gypsum added $\mathrm{Ca}$ hydroxide after phosphatization by $1 \mathrm{M} \mathrm{Na} \mathrm{PO}_{4} \cdot 12 \mathrm{H}_{2} \mathrm{O}$ for 7 days (a) and 14 days (b). Hydroxyapatite (HA) phase was detected as a main reaction product regardless of the percentage of Ca-hydroxide added into gypsum. The composition transformations into HA phase were marked by peaks development at around $2 \theta$ of $25.5^{\circ}$ and $32.5^{\circ}$. Meanwhile peaks at around $2 \theta$ of $28.5^{\circ}$ decreased in their intensity. Transformation of $\mathrm{CaCO}_{3}$ or DCPD/ $\mathrm{CaCO}_{3}$ into $\mathrm{HA}$ is seemed to proceed faster by lower concentration of added $\mathrm{Ca}(\mathrm{OH})_{2}$. In higher Ca-hydroxide concentrations (50 and $100 \%$ ), the $\mathrm{CaCO}^{3}$ peaks at around $2 \theta$ of $28.5^{\circ}$ still remained high even after 14 days hydrothermal treatment in phosphate solution. In the lower concentrations of Ca-hydroxide (20 and 40\%), the $\mathrm{CaCO}_{3}$ peaks also remained although the intensity was lower than those of with higher Ca-hydroxide concentrations. This is probably due to high $\mathrm{pH}$ in $\mathrm{Na}_{3} \mathrm{PO}_{4} \cdot 12 \mathrm{H}_{2} \mathrm{O}$ solution, which resulted in the stabilization of $\mathrm{CaCO}_{3}$ compared with carbonate apatite [22,23]. Moreover in the composition where $\mathrm{CaCO}_{3}$ remained, the peaks around $2 \theta$ of $32^{\circ}$ were merged, showing different feature with the composition without remaining $\mathrm{CaCO}_{3}$ (gypsum without added Ca-hydroxide) where it was found clear separation between (211) and (112) diffraction peaks. Regarding the peak separation, LeGeros [24] observed that the lattice parameter of a-axis in a hexagonal apatite crystal decreased with the increasing $\mathrm{CO}_{3}$ content. In this study, it was theoretically predicted that the more the percentage of Ca-hydroxide added into gypsum, the faster the composition transformation of the composite into $\mathrm{CaCO}_{3}$ monolith after carbonation.
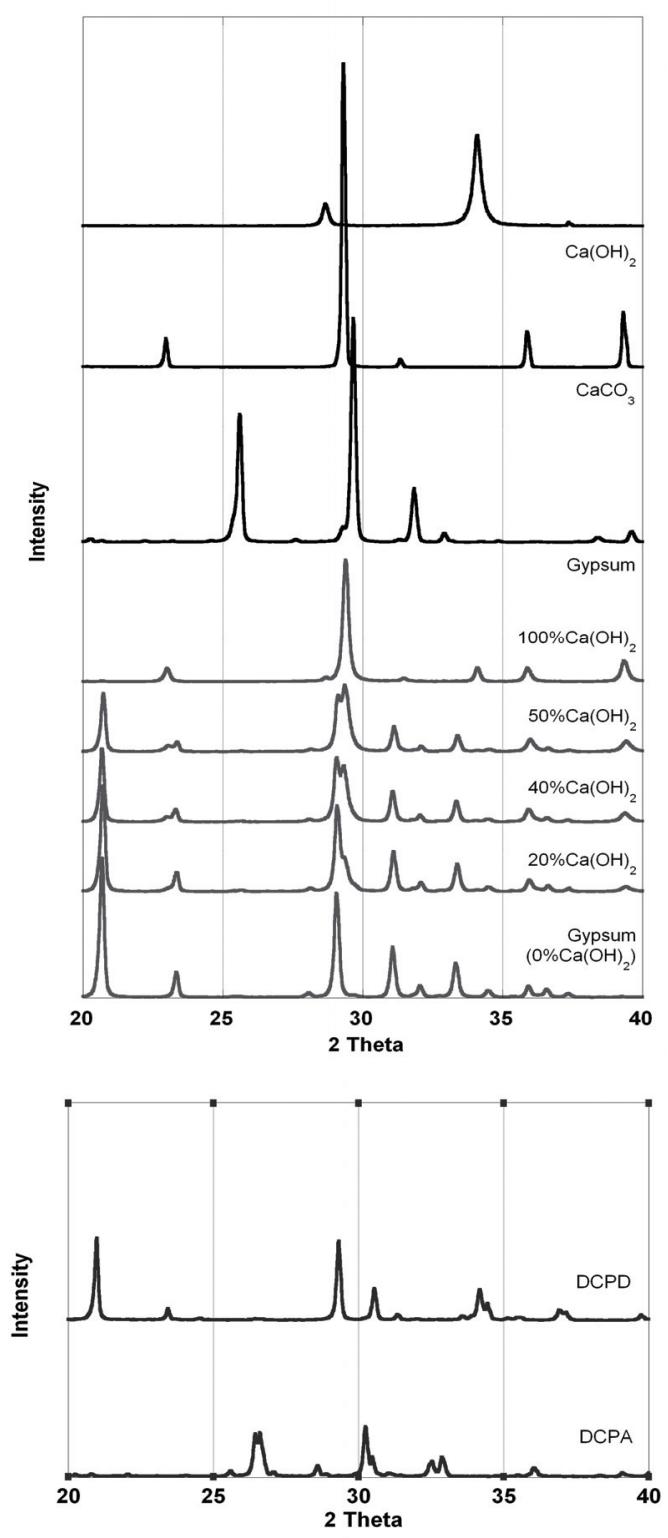

Figure 1. X-Ray diffraction patterns of gypsum added Cahydroxide after 72 hours carbonation. Peak development at around 2 of $28.5^{\circ}$ was observed regardless the amount of Ca-hydroxide additions. Another pattern shows diffraction of DCPD and DCPA for comparison. 


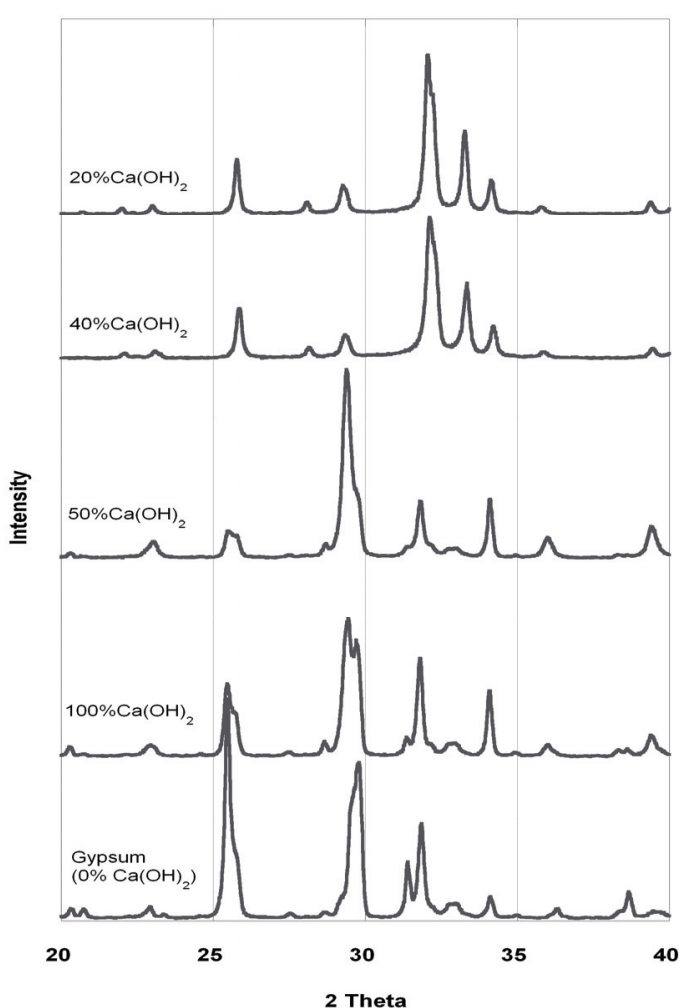

(a)

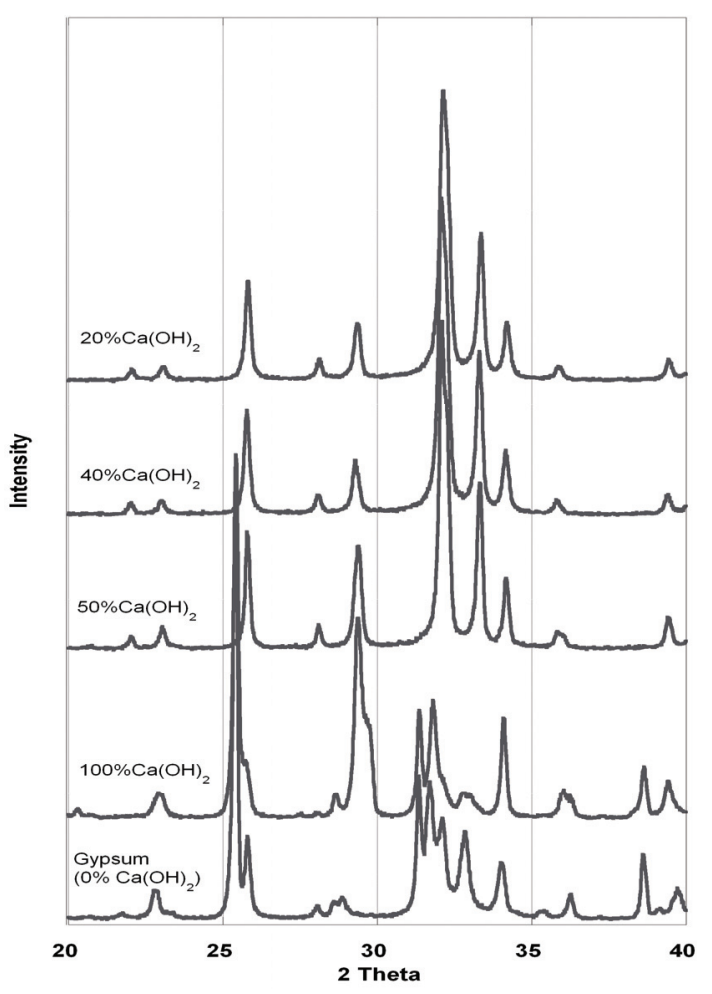

(b)

Figure 2. X-Ray diffraction patterns of gypsum added Ca-hydroxide after 7 days (a) and 14 days (b) phosphatization in $1 \mathrm{M} \mathrm{Na}_{3} \mathrm{PO}_{4} \cdot 12 \mathrm{H}_{2} \mathrm{O}$.
Table 1 summarizes the qualitative analysis of XRD showing the composition transformation after carbonation and phosphatization.

\subsection{FT-IR Spectra}

Figure 3 shows the FT-IR spectra of the specimens after carbonation and 7 days phosphatization. Although typical $\mathrm{CO}_{3}{ }^{2-}$ bands were detected between 1000 and $900 \mathrm{~cm}^{-1}$ and 1600 to $1400 \mathrm{~cm}^{-1}$ but the bands between 1600- 1400 $\mathrm{cm}^{-1}$ were broad indicating that the transformation into CHA was not completed yet by 7 days process, irrespective of the percentage of Ca-hydroxide added into gypsum. After carbonation and 7 days phoshatization, bands around $1100 \mathrm{~cm}^{-1}$ were developed in all specimens, regardless the amount of Ca-hydroxide added into gypsum. These bands were correlated with $\mathrm{PO}_{4}{ }^{3-}$ of the typical B-type CHA $[15,25,26]$ but also A-type CHA indicated by $\mathrm{CO}_{3}{ }^{2-}$ bands development at around $810-800 \mathrm{~cm}^{-1}$. The higher the amount of $\mathrm{Ca}(\mathrm{OH})_{2}$ added, the more the absorbance indicating $\mathrm{CO}_{3}{ }^{2-}$ bands at around 980-960 $\mathrm{cm}^{-1}$ was observed. The complete composition transformation into B-type CHA was detected by prolonging phosphatization to 14 days as shown in the typical composition transformation process (Figure 4).

Figures $\mathbf{4}$ and $\mathbf{5}$ show the FT-IR spectra of the process after carbonation, continued by 7 days phosphatization, and 14 days phosphatization. After 14 days phosphatization, the typical $\mathrm{CO}_{3}{ }^{2-}$ bands were developed at 1455$1410 \mathrm{~cm}^{-1}$ and $880-860 \mathrm{~cm}^{-1}$ in which the absorbance was higher by longer phosphatization period. On the same figure, the typical $\mathrm{PO}_{4}{ }^{3-}$ bands were observed at 600-560, and 1100-960 $\mathrm{cm}^{-1}$ indicating the development of B-type CHA. The $\mathrm{PO}_{4}{ }^{3-}$ band at around 600-560 was well separated. The existence of carbonate ion bands in the spectra shows the formation of $\mathrm{CO}_{3}{ }^{2-}$ substituted HA (CHA). Elliot [23] in his explanation of the structure and chemistry of apatites mentioned that B-type CHA shows $\mathrm{CO}_{3}{ }^{2-}$ band at 1410 and $1455 \mathrm{~cm}^{-1}$ while A-type at about 1545 and $1455 \mathrm{~cm}^{-1}$. In the final reaction products, the $\mathrm{CO}_{3}{ }^{2-}$ band appeared at around 1410 and $1455 \mathrm{~cm}^{-1}$.

Table 1. Qualitative analysis of XRD showing the composition transformation of gypsum added Ca-hydroxide after carbonation and phosphatization in continuous treatment.

\begin{tabular}{llll}
\hline $\begin{array}{l}\text { Content of } \\
\text { Ca-hydroxide } \\
\text { (wt\%) }\end{array}$ & $\begin{array}{l}\text { Composition } \\
\text { After 72 hours } \\
\text { Carbonation }\end{array}$ & $\begin{array}{l}\text { Composition } \\
\text { After 7 days } \\
\text { Phospatiza- } \\
\text { tion }\end{array}$ & $\begin{array}{l}\text { Composition } \\
\text { After 14 days } \\
\text { Phosphatiza- } \\
\text { tion }\end{array}$ \\
\hline $\begin{array}{l}\mathrm{Gypsum} \\
\left(0 \% \mathrm{Ca}(\mathrm{OH})_{2}\right)\end{array}$ & $\begin{array}{l}\mathrm{DCPD}, \mathrm{Gyp}- \\
\text { sum }\end{array}$ & Gypsum, $\mathrm{CHA}$ & $\mathrm{CHA}$ \\
$20 \% \mathrm{Ca}(\mathrm{OH})_{2}$ & $\mathrm{DCPD}, \mathrm{CaCO}_{3}$ & $\mathrm{CHA}, \mathrm{CaCO}_{3}$ & $\mathrm{CHA}$ \\
$40 \% \mathrm{Ca}(\mathrm{OH})_{2}$ & $\mathrm{DCPD}, \mathrm{CaCO}_{3}$ & $\mathrm{CHA}, \mathrm{CaCO}_{3}$ & $\mathrm{CHA}$ \\
$50 \% \mathrm{Ca}(\mathrm{OH})_{2}$ & $\mathrm{DCPD}, \mathrm{CaCO}_{3}$ & $\mathrm{CaCO}_{3}$ & $\mathrm{CHA}, \mathrm{CaCO}_{3}$ \\
$100 \% \mathrm{Ca}(\mathrm{OH})_{2}$ & $\mathrm{CaCO}_{3}$ & $\mathrm{CaCO}_{3}$ & $\mathrm{CHA}, \mathrm{CaCO}_{3}$ \\
\hline
\end{tabular}


This observation showed that the composition transformation reaction by carbonation and phosphatization resulted in B-type CHA. Figure 5 show extended bands found in the study. Landi et al. [18] reported that the increasing of $\mathrm{CO}_{3}{ }^{2-}$ band at about 1545 and $1455 \mathrm{~cm}^{-1}$ caused by the migration of $\mathrm{CO}_{3}{ }^{2-}$ band at 1410 and 1455 $\mathrm{cm}^{-1}$ to $\mathrm{OH}^{-}$lattice site with heat treatment caused a decrease in crystallinity. The decrease in crystallinity attributed to the ability of hydroxyl site to accept more vacancies and the increasing degree of freedom of $\mathrm{CO}_{3}{ }^{2-}$ ion. Based on that phenomenon, in this study, lower hydrothermal treatment $\left(60^{\circ} \mathrm{C}\right)$ was applied after experimenting different temperatures ranging from 100 to $60^{\circ} \mathrm{C}$ to allow formation of low crystalline B-type CHA. It was observed that the longer the phosphatization period, the lower the crystallinity obtained by composition transformation of gypsum added Ca-hydroxide ended with B-type CHA.

Table 2 summarizes the composition of CHA prepared by composition transformation of gypsum added $\mathrm{Ca}$-hydroxide. The $\mathrm{Ca} / \mathrm{P}$ molar ratio ranged between 1.53 to 2.01 molar ratio. Without $\mathrm{Ca}$-hydroxide addition into

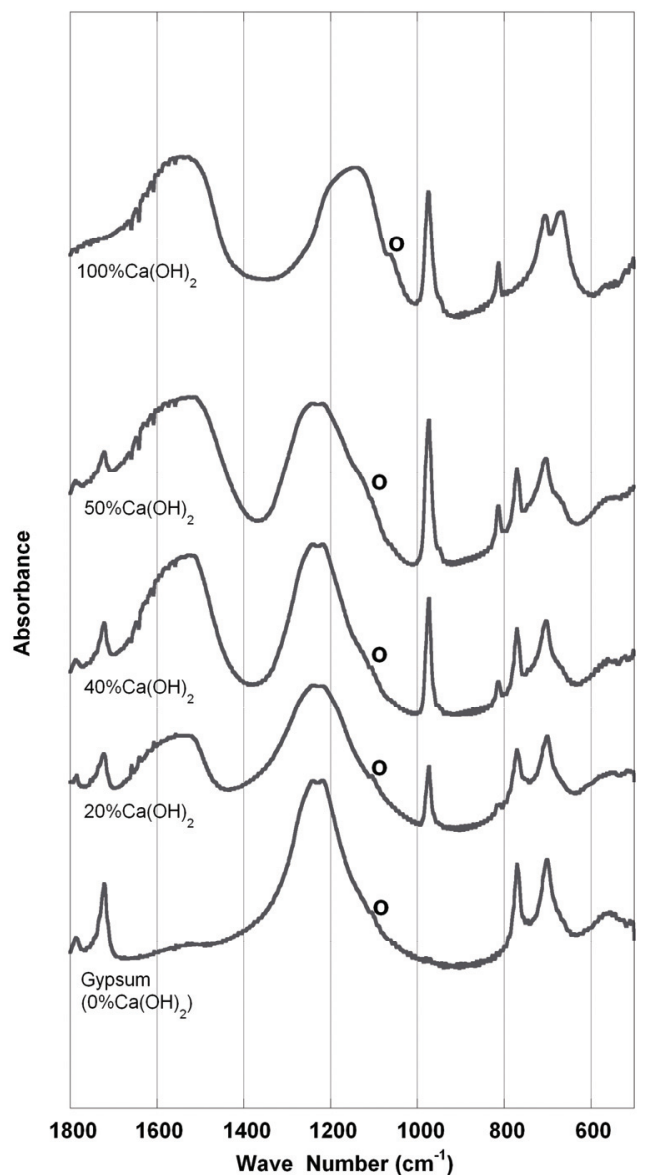

Figure 3. FT-IR spectra of the monoliths after 72 hours carbonation and 7 days phosphatization, showing CHA peaks development which was not completed.

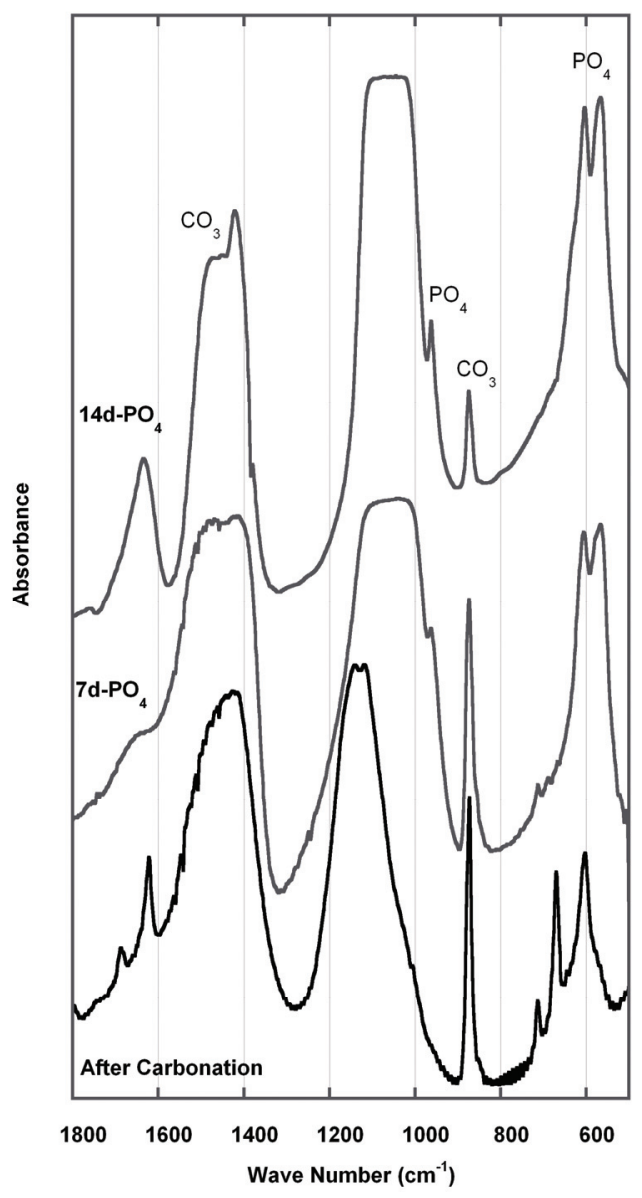

Figure 4. FT-IR spectra of gypsum added 40 weight\% Cahydroxide after carbonation, continued by 7 days phosphatization, and prolonged up to 14 days phosphatization.

Table 2. Chemical composition of CHA prepared by composition transformation of gypsum added Ca-hydroxide.

\begin{tabular}{cccc}
\hline $\begin{array}{c}\text { Content of } \\
\text { Ca-hydroxide } \\
\text { (wt\%) }\end{array}$ & $\begin{array}{c}\mathbf{C a} / \mathbf{P} \\
\text { Molar } \\
\text { ratio }\end{array}$ & $\begin{array}{c}\mathbf{C O}_{3}{ }^{2-} \\
\text { (wt\%) }\end{array}$ & $\begin{array}{c}\text { OH } \\
\text { (wt\%) }\end{array}$ \\
\hline $\begin{array}{c}\mathrm{Gypsum} \\
\left(0 \% \mathrm{Ca}(\mathrm{OH})_{2}\right)\end{array}$ & $1.53 \pm 0.04$ & 0.58 & 0.55 \\
$20 \% \mathrm{Ca}(\mathrm{OH})_{2}$ & $1.71 \pm 0.02$ & 3.36 & 0.47 \\
$40 \% \mathrm{Ca}(\mathrm{OH})_{2}$ & $1.83 \pm 0.02$ & 6.12 & 0.52 \\
$50 \% \mathrm{Ca}(\mathrm{OH})_{2}$ & $1.88 \pm 0.01$ & 3.10 & 0.53 \\
$100 \% \mathrm{Ca}(\mathrm{OH})_{2}$ & $2.01 \pm 0.02$ & 3.27 & 0.58 \\
\hline
\end{tabular}

Table 3. Qualitative analysis on setting reaction on the gypsum added Ca-hydroxide.

\begin{tabular}{cc}
\hline $\begin{array}{c}\text { Content of Ca-hydroxide } \\
\text { (wt\%) }\end{array}$ & $\begin{array}{c}\text { Setting } \\
\text { Reaction }\end{array}$ \\
\hline $\begin{array}{c}\mathrm{Gypsum} \\
\left(0 \% \mathrm{Ca}(\mathrm{OH})_{2}\right)\end{array}$ & Good \\
$20 \% \mathrm{Ca}(\mathrm{OH})_{2}$ & Good \\
$40 \% \mathrm{Ca}(\mathrm{OH})_{2}$ & Good \\
& Poor \\
$50 \% \mathrm{Ca}(\mathrm{OH})_{2}$ & (Difficult to handle) \\
$100 \% \mathrm{Ca}(\mathrm{OH})_{2}$ & Very Poor \\
& (Very difficult to handle) \\
\hline
\end{tabular}



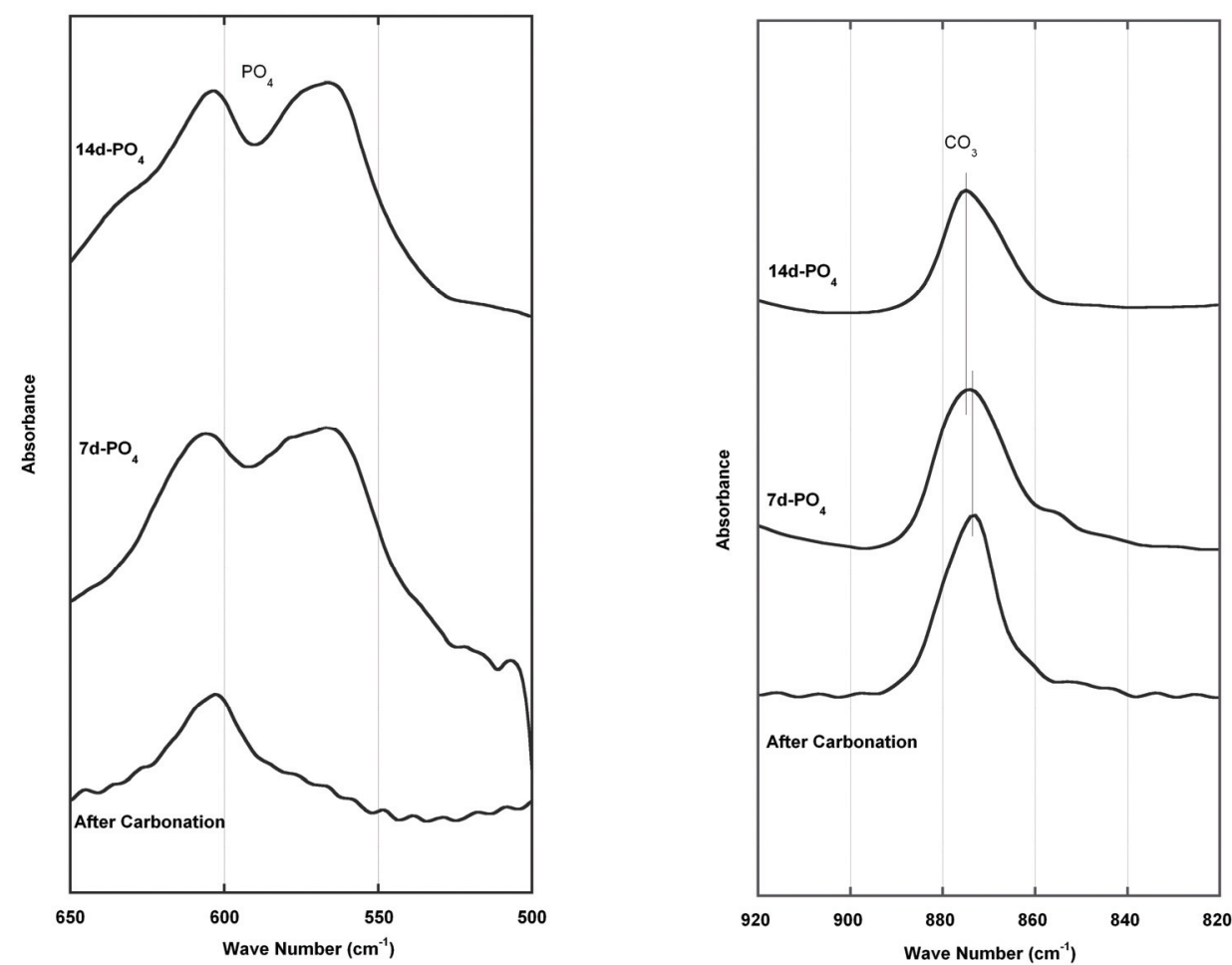

Figure 5. Extended $\mathrm{CO}_{3}{ }^{2-}$ and $\mathrm{PO}_{4}{ }^{3-}$ bands of FT-IR spectra found by composition transformation reaction.

gypsum, the $\mathrm{Ca} / \mathrm{P}$ ratio was slightly lower than that of stoichiometric HA, that is 1.67 , indicating that calcium deficient apatite was formed. By addition of Ca-hydroxide into gypsum followed by carbonation and phosphatization treatment using $\mathrm{Na}_{3} \mathrm{PO}_{4} \cdot 12 \mathrm{H}_{2} \mathrm{O}$, the $\mathrm{Ca} / \mathrm{P}$ ratio are 1.71 , $1.83,1.88$, and 2.01 molar ratio for $20,40,50$, and $100 \%$ additions respectively. These results showed that by $\mathrm{Ca}-$ hydroxide additions, $\mathrm{PO}_{4}{ }^{3-}$ was replaced by $\mathrm{CO}_{3}{ }^{2-}$ which led to the formation of B-type CHA.

The $\mathrm{CO}_{3}{ }^{2-}$ content of the specimens ranging from 0.58 (for gypsum without Ca-hydroxide addition), 3.10, 3.27, and 3.36 for 50, 100, and 20 weight $\%$ Ca-hydroxide additions respectively, to 6.12 weight $\%$ (for the specimen with 40 weight $\%$ Ca-hydroxide addition). Only by addition of 40 weight $\%$ Ca-hydroxide the carbonate content resulted by composition transformation is on the range of bone mineral, that is $4-8$ weight $\%[9,10]$.

Figure 6 shows SEM photographs of CHA obtained in various addition of Ca-hydroxide. Without addition of Ca-hydroxide into gypsum, the CHA crystal showed a needle like apatite morphology after carbonation and phosphatization reaction (Figure 6(b)). By 20 weight\% addition of Ca-hydroxide into gypsum, the CHA resulted both a needle like morphology and fine globular crystal (Figure 6(d)). Increasing the amount of Ca-hydroxide (to 40 and 50 weight $\%$ ) added into gypsum resulted in fine globule-like CHA crystals (Figure 6(f) and 6(h)). Inter connective porosity is observed on the microstruc- ture of the monoliths.

Figure 7 shows the changes in DTS (diametral tensile strength) of the specimens. The mechanical strength increased after carbonation and phosphatization reactions, and the increased strength after carbonation and phosphatization was found $50 \%$ in pure set Ca-hydroxide, $25 \%$ in gypsum added by 20 or 40 weight $\%$ of Ca- hydroxide, $20 \%$ in gypsum added by 50 weight $\%$ of $\mathrm{Ca}$ hydroxide, and remained the same in the gypsum without Ca-hydroxide addition. The difference in DTS is probably due to the crystallite size and shape of the specimens.

In this study, we investigated the effect of added Cahydroxide to gypsum, carbonation and phosphatization temperatures and periods to understand the basic principle of composition-transformation of gypsum added $\mathrm{Ca}$ hydroxide to fabricate carbonate apatite bone substitutes. It was observed that faster transformation was achieved with higher hydrothermal temperature. However, higher hydrothermal temperature caused de-carbonation phenomena which resulted in the lack of carbonate ions in the product. Decreasing phosphatization temperatures required longer reaction periods. Moreover, the higher the percentage of Ca-hydroxide added to gypsum resulted in slower complete transformation of gypsum into $\mathrm{CHA}$, indicated by remaining $\mathrm{CaCO}_{3}$ phase inside the composition. These findings have been applied to the standard fabrication procedure of carbonate apatite that is provided for biomedical purposes in Indonesia. Cell studies and in vivo animal studies are being carried out 


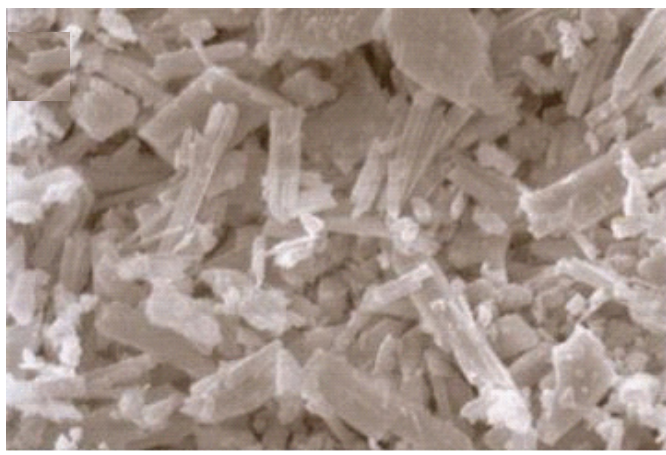

(a)

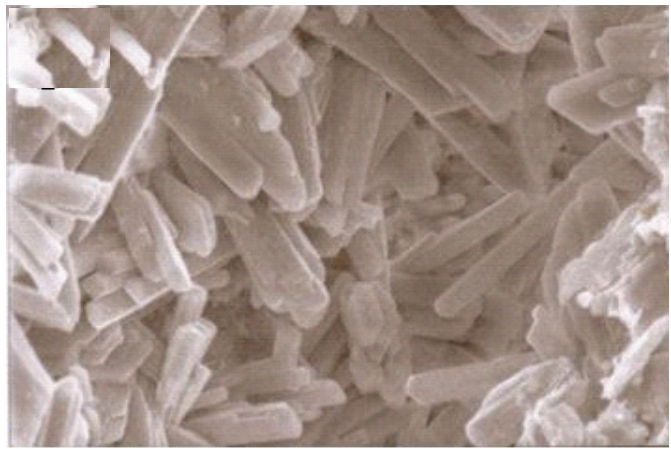

(c)

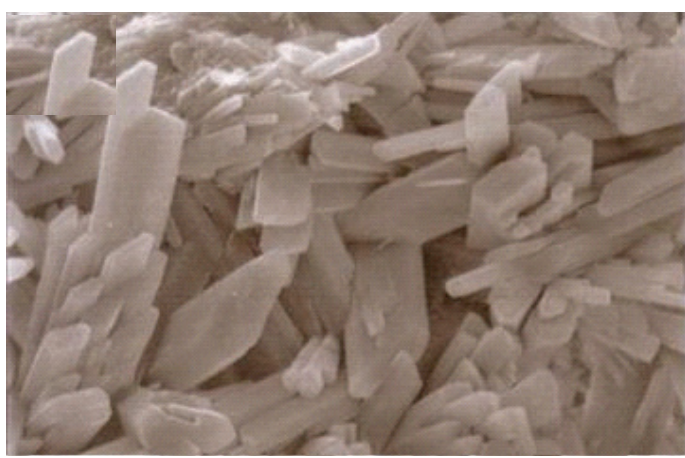

(e)

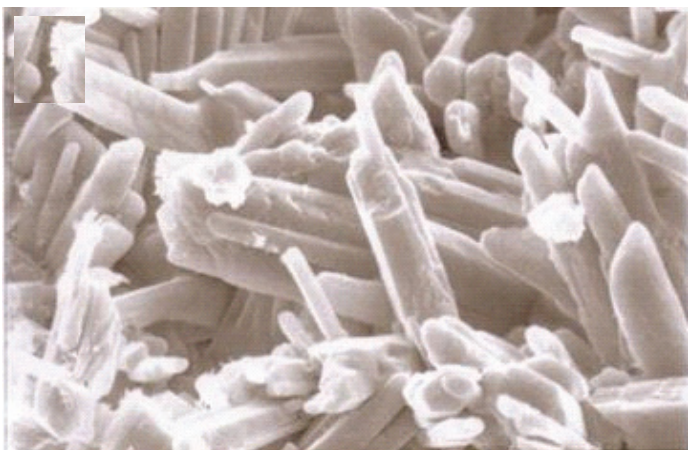

(g)

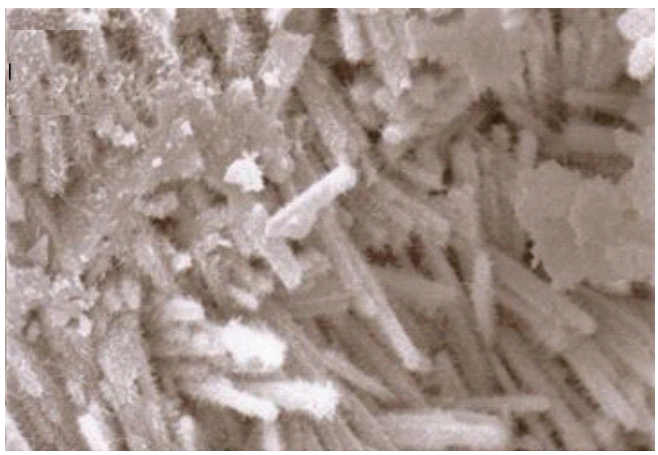

(b)

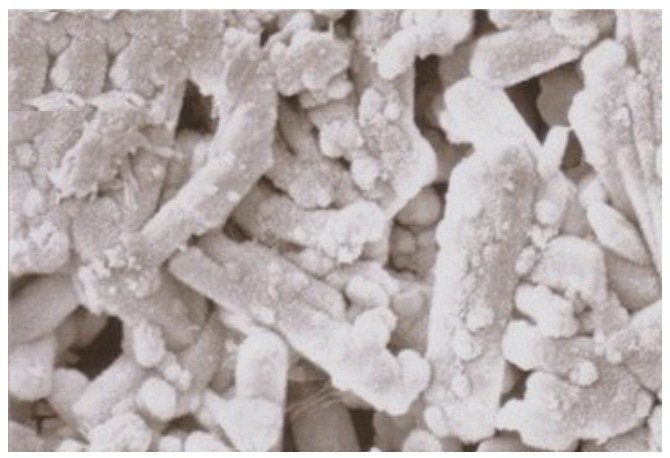

(d)

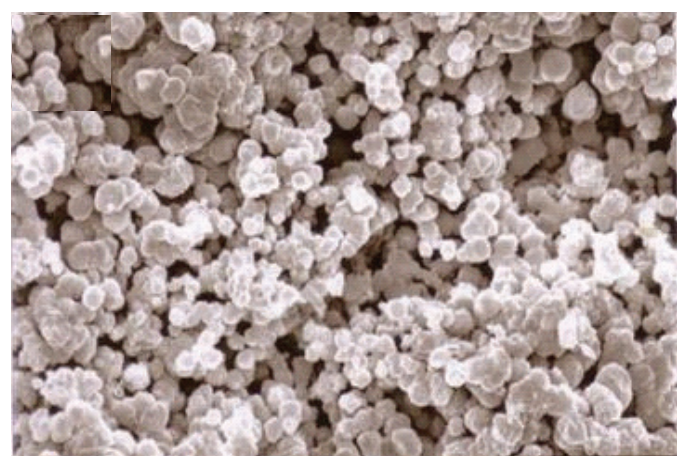

(f)

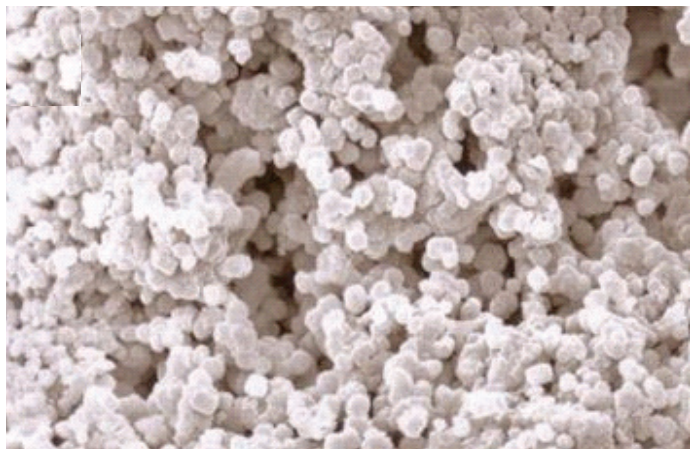

(h)

Figure 6. Scanning electron microscopic observation of set gypsum, gypsum added Ca-hydroxide by 20,40 , and 50 weight\% before treatment (a, c, e, g) and after carbonation and phosphatization (b, $d, f, h)$. 


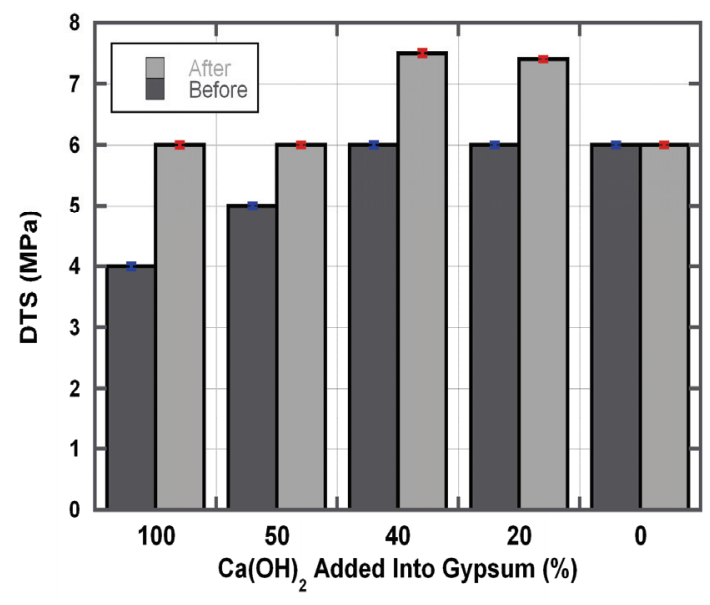

Figure 7. Changes in DTS (MPa) before and after carbonation and phosphatization reactions.

in our laboratory. For the continuation of these studies, it is suggested to start preliminary clinical trials, so as to have an overview study to scale up fabrication, and to precede valorization and actual bone substitute production for the Indonesian market.

\section{Acknowledgements}

This study was a part of series of research collaboration supported by first batch bilateral joint program JSPSDGHE (Japan Society for the Promotion of ScienceDirectorate General of Higher Education of the Republic of Indonesia).

\section{References}

[1] C. J. Kirkpatrick, S. Fuchs, K. Peters, C. Brochhausen, M. I. Hermanns and R. E. Unger, "Visions for Regenerative Medicine: Interface between Scientific Fact and Science Fiction," Artif Organs, Vol. 30, 2006, pp. 822-827.

[2] W. L. Murphy and D. J. Mooney, "Bioinspired Growth of Crystalline Carbonate Apatite on Biodegradable Polymer Substrata," Journal of the American Chemical Society, Vol. 124, 2002, pp. 1910-1917.

[3] S. C. G. Leeuwenburgh, I. D. Ana and J. Jansen, "Sodium Citrate as an Effective Dispersant for Synthesis of Inorganic-Organic Composites with Nanodispersed Mineral Phase," Acta Biomaterialia, 2009.

[4] J. V. Rau, S. N. Cesaro, D. Ferro, S. M. Barinov and J. V. Fadeeva, "FTIR Study of Carbonate Loss from Carbonated Apatites in Wide Temperature Range," Journal of Biomedical Materials Research Part B: Applied Biomaterials, Vol. 71B, No. 2, 2004, pp. 441-447.

[5] A. A. Baig, J. L. Fox, J. Su, Z. Wang, M. Otsuka, W. I. Higuchi and R. Z. Legeros, "Effect of Carbonate Content and Crystallinity on the Metastable Equilibrium Solubility Behavior of Carbonate Apatite," Journal of Colloid and Interface Science, Vol. 179, 1996, pp. 608-617.

[6] R. Tang, Z. J. Henneman and G. H. Nancollas, "Size Effects in the Dissolution of Hydroxyapatite an Understanding Biological Demineralization," Journal of Crystal Growth, Vol. 249, 2003, p. 614.

[7] I. Y. Rieters, E. A. P. D. Maeyer and R. M. H Verbeeck, "Conversion of Octacalcium Phosphate in Calcium Phosphate Cements," Inorganic Chemistry, Vol. 35, 1996, p. 5791.

[8] H. R. Wenk, F. Heidelbach, "Crystal Alignment of Calcium Phosphate in Bone and Calcified Tendon," Bone, Vol. 24, No. 4, 1999, pp. 361-369.

[9] E. Landi, A. Tampieri, G. Celotti, R. Langenati, M. Sandri, S. Sprio, "Influence of Synthesis and Sintering Parameters on the Characteristics of Calcium Phosphate," Biomaterials, Vol. 26, 2005, p. 2835.

[10] J. Barralet, S. Best and W. Bonfield, "Carbonate Substitution in Precipitated Hydroxyapatite: An Investigation into Effects of Reaction Temperature and Bicarbonate Ion Concentration," Journal of Biomedical Materials Research, Vol. 41, No. 1, 1998, p. 79.

[11] J. Barralet, M. Akao, H. Aoki, "Dissolution of Dense Carbonate Apatite Subcutaneously Implanted in Wistar Rats," Journal of Biomedical Materials Research, Vol. 49, No. 2, 2000, pp. 176-182.

[12] W. L. Suchanek, P. Shuk, K. Byrappa, R. E. Riman, K. S. Tenhuisen, V. F. Janas, "Mechanochemical-Hydrothermal Synthesis of Carbonated Apatite Powders at Room Temperature," Biomaterials, Vol. 23, 2002, pp. 699-710.

[13] S. A. Redey, M. Nardin, D. B. Assolant, C. Rey, P. Delannoy, L. Sedel, P. J. Marie, "Behavior of Human Osteoblastic Cells on Stoichiometric Hydroxyapatite and Type-A Carbonated Apatite," Journal of Biomedical Materials Research, Vol. 50, No. 3, 2000, p. 353.

[14] J. E. Barralet, S. Aldred, A. J. Wright and A. G. A. Coombes, "In Vitro Behavior of Albumin Loaded Carbonated Hydroxyapatite Gel," Journal of Biomedical Materials Research, Vol. 60, 2002, pp. 360-367.

[15] T. Matsumoto, M. Okazaki, M. Inoue, S. Ode, C. C. Chien, H. Nakao, Y. Hamada and J. Takahashi, "Biodegradation of Carbonate Apatite/Collagen Composite Membrane and Its Controlled Release Carbonate Apatite," Journal of Biomedical Materials Research, Vol. 60, 2002, pp. 651-656.

[16] J. E. Barralet, S. M. Best and W. Bonfield, "Effect of Sintering Parameters on the Density and Microstructure of Carbonate Hydroxyapatite," Journal of Materials Science: Materials in Medicine, Vol. 11, 2000, pp. 719-724.

[17] L. M. Oliverira, A. M. Rossi and R. T. Lopes, "Configuration of CO Radicals in Type-A and B Carbonate Apatite," Applied Radiation and Isotopes, Vol. 52, 2000, p. 1093.

[18] E. Landi, A. Tampieri, G. Celotti, L. Vichi and M. Sandri, "Influence of Synthesis and Sintering Parameters of Carbonate Apatite," Biomaterials, Vol. 25, 2004, pp. 1763- 
1770.

[19] M. E. Fleet and X. Liu, "Site Preference of Rare Earth Lements in Hydroxyapatite," Journal of Solid State Chemistry, Vol. 174, 2003, p. 412.

[20] J. Fricain, L. Bareille, F. Ulysse, B. Dupuy, J. Amdee, "Evaluation of Proliferation and Protein Expression of Human Bone Marrow Cells Cultured on Coral Crystallized in the Aragonite or Calcite Form," Journal of Biomedical Materials Research, Vol. 42, 1998, p. 96.

[21] R.W. Evans, H. S. Cheung and D. J. Mc Carty, "Cultured Human Monocytes and Fibroblasts Solubilize Calcium Phosphate Crystals," Calcified Tissue International, Vol. 36, 1984, pp. 645-650.

[22] Y. Lee, Y. M. Hahm, S. Matsuya, M. Nakagawa and K. Ishikawa, "Characterization of Macroporous Hydroxiapatite Bodies Prepared in Different Phosphate Solution,"
Journal of Materials Science, Vol. 42, 2007, pp. 78437849 .

[23] G. Verveecke and J. Lemaitre, "Calculation of the Solubility Diagrams in the System of Carbonate Apatite," Journal of Crystal Growth, Vol. 104, 1990, p. 820.

[24] R. Z. Legeros and O. R. Trautz, "Apatite Crystallites, Effects of Carbonate on Morphology," Science, Vol. 155, No. 3768, 1967, pp. 1409-1411.

[25] A. Bouhaouss, A. Bensaoud, A. Laghzizil and M. Ferhat, "Mechanism of Ionic Conduction in Oxy and Hydroxyapatite Structure," International Journal of Inorganic Materials, Vol. 3, No. 7, November 2001, pp. 743-747.

[26] J. C. Elliot, "Structure and Chemistry of Apatite and Other Calcium Orthophosphates," Studies in Inorganic Chemistry 18, Elsevier, Amsterdam, Vol. 230, 1994. 